\title{
БIOXIMIЯ
}

УДК 577.115.3+161.536:591.1

doi: 10.25128/2078-2357.19.3.4

${ }^{1}$ О. В. ЯКОВІЙЧУК, ${ }^{1,2}$ О. О. ДАНЧЕНКО, ${ }^{2}$ М. М. ДАНЧЕНКО, ${ }^{1}$ А. С. ФЕДОРКО,

${ }^{1}$ I. О. КУЛИК

${ }^{1}$ Мелітопольський державний педагогічний університет імені Богдана Хмельницького

вул. Гетьманська, 20, Мелітополь, Запорізька область, 72312

${ }^{2}$ Таврійський державний агротехнологічний університет імені Дмитра Моторного

пр. Б. Хмельницького, 18, Мелітополь, Запорізька область, 72312

e-mail: alex.yakov1991@gmail.com

\section{ЖИРНОКИСЛОТНИЙ СКЛАД МІОКАРДУ ГУСЕЙ ЗА ДІї ВІКАСОЛУ}

Вікасол проявляє активність щодо енергетичної та антиоксидантної систем тканин, які тісно пов'язані з біосинтезом та окисненням жирних кислот. Така активність дозволяє припустити, що вікасол здатен викликати зміни жирнокислотного складу тканин, а численні роботи стосовно позитивного впливу хінонів та їхніх похідних на функціональний стан міокарду, дозволяють вважати, що вірно підібрана доза та технологія згодовування здатні підвищити опірність та продуктивність сільськогосподарської птиці. У роботі досліджено вплив вікасолу на жирнокислотний склад міокарду гусей. Установлено, що за рахунок різноспрямованих змін умісту всього спектру жирних кислот тканини впродовж експерименту, застосування вікасолу викликає незначне підвищення ненасиченості і загального вмісту ненасичених жирних кислот у міокарді гусей. Коливання реалізуються залежно від фізіологічного стану організму, де вікасол може стимулювати як процеси біосинтезу окремих жирних кислот, так i ïx мітохондріальне та мікросомальне окиснення, що підтверджується різноспрямованими достовірними змінами вмісту всього їх спектру. Зокрема, на 21-шу добу підвищується вміст докозопентаєнової кислоти на $36,3 \%$ при зниженні докозогексаєнової і ліноленової кислот в середньому на 21-24\%. На 28-му добу підвищується концентрація ейкозатетраєнової і докозогексаєнової кислот при зниженні кількості лінолевої на 22,6\% відносно контрольної групи. На 35-ту добу вміст основних ненасичених жирних кислот (пальмітоолеїнової, лінолевої, ліноленової і докозогексаєнової) підвищується у тканині за дії вікасолу при повному виснаженні докозопентаєнової кислоти. Дані коливання жирнокислотного складу викликають незначне підвищення загального вмісту ненасичених жирних кислот та підвищення ненасиченості ліпідів міокарду на 28-му і 35-ту добу онтогенезу гусей. Доведено, що вікасол може бути використано у сільськогосподарській практиці як інструмент підвищення якості продукції птахівництва та опірності сільськогосподарської птиці.

Ключові слова: вікасол, жирні кислоти, міокард, гуси.

Жирнокислотний склад тваринних тканин пов'язаний з багатьма важливими параметрами організму, такими, як аеробна витривалість, швидкість метаболізму, періоди відновлення після фізичного навантаження та ін. Це пов'язано з тим, що хімічні властивості жирних кислот сильно впливають на їх функціонування в біологічних системах, формуючи внесок у структуру клітин, міжклітинну сигналізацію, регуляцію експресії генів та зберігання енергії [5]. 
Наприклад, плинність і проникність біологічних мембран, активність деяких ензимів, пов'язаних із клітинною мембраною, а також біохімічна доступність внутрішньоклітинних запасів енергії залежать від жирнокислотного складу [2, 7]. Стійкість до окисного пошкодження [10, 28, 37] та реалізація внутрішньоклітинної сигналізації [5] залежать від кількості та характеру розміщення подвійних зв’язків у карбоновому ланцюзі жирних кислот. Таким чином, аналіз жирнокислотного складу тканин $\epsilon$ способом прогнозування функціонального стану систем організму. Хоча жирнокислотний склад мембран і запасних ліпідів відіграє важливу роль у фізіологічних функціях, він може динамічно змінюватись у відповідь на ендогенні та екзогенні чинники. Ендогенні впливи включають коливання активності ліпогенних ензимів, які модифікують жирні кислоти [27]. Основним екзогенним чинником є дієтична доступність жирних кислот [5, 19], яка залежить від раціону [14]. 3 іншого боку, зміни жирнокислотного складу тканини можуть бути спровоковані біологічно-активними речовинами, наприклад, хінонами, які володіють широким спектром дії $[4,22]$, що залежить від їх дози і структури $[8,33]$.

Вікасол здебільшого використовується як токсикант у моделюванні оксидаційного стресу $[11,33]$. За останні роки дослідження фармакологічних властивостей хінонів значно активізувались $[3,8,11,13,24,31]$, хоча їх вплив на жирнокислотний склад тканин вивчено не достатньо. Описано вплив вікасолу на процеси транскрипції та активації чинників, які задіяні у ланцюгу антиоксидантної відповіді клітини. Виходячи з цих даних, вікасол може викликати в міокарді зміни жирнокислотного складу тканин, а правильно підібрана доза препарату забезпечить підвищення опірності організму до негативних чинників, що може бути використано при виборі технології годування та лікування сільськогосподарської птиці. У той же час позитивний ефект на функціональний стан міокарду підтверджується широким застосуванням хінонів як кардіопротекторних препаратів [9, 15, 21, 34].

Метою роботи було з'ясувати вплив вікасолу на жирнокислотний склад м'язової тканини серця гусей.

\section{Матеріали і методи досліджень}

Як модельний об'єкт використовували гусей породи Легард Великий (Білий). У 1-добовому віці було сформовано 2 групи (контрольна та дослідна) по 25 голів у кожній. Гусенят дослідної групи з 3-ї доби пропоювали водним розчином вікасолу з концентрацією 10 мг/л щоденно із розрахунку 0,7 мг/кг маси тіла [35]. Запропонована доза вікасолу визначена 3 урахуванням токсичності препарату при більших концентраціях [1, 17].

Дослідження жирнокислотного складу ліпідів міокарду за дії вікасолу проводили в період з 21-ї до 35-ї доби постнатального онтогенезу, який характеризується фізіологічною напругою початку формування контурного пір'я.

Уміст жирних кислот визначали методом газорідинної хроматографії. Підготовку екстракту до аналізу проводили за методом Ф. Палмера [25]. Жирнокислотний склад ліпідів визначали на хроматографі Carlo Erba, як носій використовували Chromosorb W/DP із фазою Silar 5CP («Serva», Німеччина) концентрацією $10 \%$ за температури $140-250{ }^{\circ} \mathrm{C}$ та швидкістю наростання $2^{\circ} \mathrm{C} / \mathrm{xв}$ (температура інжектора $210^{\circ} \mathrm{C}$, температура детектора $240^{\circ} \mathrm{C}$ ). Окрім сумарного вмісту ненасичених жирних кислот (НЖК) ( $\Sigma \mathrm{C})$ розраховували сумарну еквівалентну концентрацію НЖК відносно кратних зв'язків (ненасиченість, $\Sigma \mathrm{N}$ ) мМоль г-1.

Статистичну обробку результатів проводили із застосуванням пакету програм MS Excel2013 та SPSS v.23 та t-критерію Стьюдента. За $\mathrm{p} \leq 0,05$ різницю вважали статистично значущою.

\section{Результати досліджень та їх обговорення}

За результатами дослідження встановлено, що застосування вікасолу викликає незначне підвищення ненасиченості і загального вмісту НЖК у міокарді гусей (табл. 1). Дані коливання реалізуються за рахунок різноспрямованих змін умісту всього спектру жирних кислот тканини впродовж експерименту. 
Жирнокислотний склад ліпідів міокарду гусей контрольної та дослідної груп ( $\omega$ - масова частка, \%; $\mathrm{N}$ - ненасиченість ЖК, ммоль/г) $(\mathrm{M} \pm \mathrm{m}, \mathrm{n}=5)$

\begin{tabular}{|c|c|c|c|c|c|c|}
\hline \multirow{3}{*}{$\begin{array}{l}\text { Fatty } \\
\text { acids }\end{array}$} & \multicolumn{6}{|c|}{ Age, days } \\
\hline & \multicolumn{3}{|c|}{ Control group } & \multicolumn{3}{|c|}{ Experimental group } \\
\hline & 21 & 28 & 35 & 21 & 28 & 35 \\
\hline$(12: 0)$ & $0,024 \pm, 001$ & $0,027 \pm, 001$ & $0,034 \pm 0,002$ & $0,040 \pm 0,002^{*}$ & $0,068 \pm 0,003 *$ & $0,027 \pm 0,001 *$ \\
\hline$(12: 1)$ & $0,045 \pm 0,002$ & $0,11 \pm 0,006$ & $0,095 \pm 0,005$ & $0,121 \pm 0,006^{*}$ & $0,161 \pm 0,008^{*}$ & $0,073 \pm 0,004 *$ \\
\hline$(13: 0)$ & - & - & - & - & $0,014 \pm 0,001 *$ & $0,018 \pm 0,001^{*}$ \\
\hline$(14: 0)$ & $0,190 \pm 0,01$ & $0,183 \pm 0,009$ & $0,165 \pm 0,008$ & $0,186 \pm 0,009$ & $0,137 \pm 0,007 *$ & $0,275 \pm 0,014^{*}$ \\
\hline$(14: 1)$ & - & - & - & - & - & $0,033 \pm 0,002 *$ \\
\hline$(15: 1)$ & $0,028 \pm 0,001$ & $0,020 \pm 0,001$ & $0,028 \pm 0,001$ & $0,018 \pm 0,001 *$ & $-*$ & $0,047 \pm 0,002 *$ \\
\hline$(16: 0)$ & $21,376 \pm 1,07$ & $20,080 \pm 1,000$ & $19,679 \pm 0,98$ & $19,040 \pm 0,950$ & $20,866 \pm 1,040$ & $18,118 \pm 0,910$ \\
\hline$(16: 1)$ & $1,117 \pm 0,056$ & $1,062 \pm 0,053$ & $1,264 \pm 0,063$ & $1,014 \pm 0,051$ & $1,051 \pm 0,053$ & $2,507 \pm 0,125^{*}$ \\
\hline$(17: 0)$ & $0,121 \pm 0,006$ & $0,143 \pm 0,007$ & $0,149 \pm 0,007$ & $0,100 \pm 0,005^{*}$ & $0,099 \pm 0,005^{*}$ & $0,183 \pm 0,009^{*}$ \\
\hline$(17: 1)$ & - & $0,038 \pm 0,002$ & $0,048 \pm 0,002$ & $0,045 \pm 0,002^{*}$ & $0,073 \pm 0,004 *$ & $0,070 \pm 0,004 *$ \\
\hline$(18: 0)$ & $20,893 \pm 1,050$ & $21,233 \pm 1,060$ & $19,469 \pm 0,97$ & $19,518 \pm 0,980$ & $19,155 \pm 0,960$ & $18,053 \pm 0,900$ \\
\hline$(18: 1)$ & $24,067 \pm 1,200$ & $25,258 \pm 1,260$ & $24,361 \pm 1,22$ & $23,780 \pm 1,190$ & $25,758 \pm 1,290$ & $22,210 \pm 1,110$ \\
\hline$(18: 2)$ & $12,826 \pm 0,640$ & $11,701 \pm 0,590$ & $12,696 \pm 0,64$ & $12,738 \pm 0,640$ & $9,543 \pm 0,480^{*}$ & $15,090 \pm 0,750 *$ \\
\hline$(18: 3)$ & $0,453 \pm 0,023$ & $0,303 \pm 0,015$ & $0,643 \pm 0,032$ & $0,366 \pm 0,018^{*}$ & $0,331 \pm 0,017$ & $0,976 \pm 0,049^{*}$ \\
\hline$(20: 0)$ & $0,729 \pm 0,036$ & $0,907 \pm 0,045$ & $0,858 \pm 0,043$ & $0,793 \pm 0,040$ & $0,755 \pm 0,038^{*}$ & $1,200 \pm 0,060^{*}$ \\
\hline$(20: 1)$ & $0,323 \pm 0,016$ & $0,274 \pm 0,014$ & $0,31 \pm 0,016$ & $0,424 \pm 0,021^{*}$ & $0,257 \pm 0,013$ & $0,474 \pm 0,024^{*}$ \\
\hline$(20: 2)$ & $0,721 \pm 0,036$ & $0,613 \pm 0,031$ & $0,646 \pm 0,032$ & $0,698 \pm 0,035$ & $0,624 \pm 0,031$ & $0,600 \pm 0,030$ \\
\hline$(20: 3)$ & $0,353 \pm 0,018$ & $0,312 \pm 0,016$ & $0,329 \pm 0,016$ & $0,362 \pm 0,018$ & $-*$ & $0,344 \pm 0,017$ \\
\hline$(20: 4)$ & $12,622 \pm 0,63$ & $13,862 \pm 0,690$ & $15,084 \pm 0,75$ & $11,358 \pm 0,570$ & $16,492 \pm 0,830 *$ & $15,160 \pm 0,760$ \\
\hline$(22: 0)$ & $1,239 \pm 0,062$ & $1,542 \pm 0,077$ & $1,353 \pm 0,068$ & $1,810 \pm 0,091^{*}$ & $1,491 \pm 0,075$ & $1,147 \pm 0,057$ \\
\hline$(22: 1)$ & - & $0,324 \pm 0,016$ & $0,162 \pm 0,008$ & $0,220 \pm 0,011^{*}$ & $0,289 \pm 0,014$ & $0,169 \pm 0,008$ \\
\hline$(24: 0)$ & $0,347 \pm 0,017$ & $0,295 \pm 0,015$ & $0,371 \pm 0,019$ & $0,391 \pm 0,020$ & $0,238 \pm 0,012 *$ & $0,479 \pm 0,024$ \\
\hline$(22: 3)$ & $0,265 \pm 0,013$ & $0,220 \pm 0,011$ & $0,279 \pm 0,014$ & $0,454 \pm 0,023^{*}$ & $0,298 \pm 0,015^{*}$ & $0,332 \pm 0,017$ \\
\hline$(22: 4)$ & $0,185 \pm 0,009$ & $0,146 \pm 0,007$ & $0,207 \pm 0,01$ & $0,480 \pm 0,024^{*}$ & $0,158 \pm 0,008$ & $0,193 \pm 0,010$ \\
\hline$(22: 5)$ & $0,450 \pm 0,023$ & - & $0,390 \pm 0,02$ & $0,706 \pm 0,035^{*}$ & - & $-*$ \\
\hline$(22: 6)$ & $0,709 \pm 0,035$ & $0,597 \pm 0,030$ & $0,696 \pm 0,035$ & $0,585 \pm 0,029^{*}$ & $0,733 \pm 0,037 *$ & $1,265 \pm 0,063 *$ \\
\hline$(24: 1)$ & $0,578 \pm 0,029$ & $0,483 \pm 0,024$ & $0,528 \pm 0,026$ & $1,638 \pm 0,082 *$ & $0,632 \pm 0,032 *$ & $0,538 \pm 0,027$ \\
\hline$\sum \mathrm{C}, \%$ & 54,700 & 55,300 & 57,800 & 55,000 & 56,400 & 60,100 \\
\hline$\sum \mathrm{N}$ & 387,200 & 388,000 & 421,600 & 378,800 & 410,100 & 445,900 \\
\hline
\end{tabular}

Примітка: тут і в таблиці 2 різниця вірогідна із контролем на рівні * - $\leq \leq 0,05$.

Зокрема, застосування вікасолу на 21-шу добу онтогенезу ініціює процеси перетворення ліноленової кислоти у докозопентаєнову та єйкозотетраєнову, що підтверджується зниженням iï вмісту на 19,2\% (p $\leq 0.05)$ та підвищенням концентрації $22: 4$ і $22: 5$ на $159,5 \%$ ( $\leq \leq 0.05)$ i 56,9\% (p $\leq 0.05$ ). Зміни реалізуються шляхом активації відповідних елонгаз та десатураз- $\Delta 4$ і $\Delta 5$ [6]. У той же час блокується конвертація докозопентаєнової кислоти у докозогексаєнову, уміст якої у цей період нижчий на $17,5 \%(\mathrm{p} \leq 0.05)$ відносно контрольної групи. Це може бути пов' язано 3 участю цієї кислоти в механізмах передачі нервових імпульсів $[12,26]$, що $є$ важливим фактором у функціонуванні серцевого м'яза. Також відомо про участь докозогексаєнової 34 ISSN 2078-2357. Наук. зап. Терноп. нац. пед. ун-ту. Сер. Біол., 2019, № 3 (77) 
кислоти в механізмах модифікації складу фосфоліпідів клітинних мембран кардіоміоцитів, що впливає на іонні канали та транспортери [18] і може бути пов'язано із функціонуванням серцевого м'яза. Додатково в цей період спостерігається накопичення інших ненасичених жирних кислот у дослідній групі 20:1, 22:1 22:3 і 24:1 на 31,3\% (p $\leq 0.05), 100 \%$ (p $\leq 0.05), 71,3 \%$ (p $\leq 0.05)$ i $183,4 \%(\mathrm{p} \leq 0.05)$ відносно контролю.

На 28-му добу онтогенезу вікасол запускає каскад біотрансформації ліноленової та ейкозатриєнової кислот в арахідонову [6], уміст якої збільшується на 19,0\% (p $\leq 0.05)$ відносно контрольної групи, відповідно концентрація 18:2 знижується на $18,4 \%$ ( $\leq \leq 0.05)$ і повністю використовується 20:3 (p $\leq 0.05$ ), що, вірогідно, $\epsilon$ причиною повного виснаження 22:5, оскільки зазначена жирна кислота може бути синтезована із 18:2 через проміжне утворення 20:3 [29]. Накопичення арахідонової кислоти в період формування контурного пір'я $є$ логічним, адже вона відіграє важливі функції в організмі: входить до складу фосфоліпідів клітинних мембран, взаємодіє з білковими комплексами і тим самим впливає на функціонування рецепторів клітин, транспортних та сигнальних систем [18], що на фоні інтенсифікації анаболічних процесів $\epsilon$ необхідною умовою. Окрім цього, ця кислота бере участь у синтезі гормонів місцевої дії тромбоксанів і лейкотрієнів, які підвищують проникність клітинних мембран у тканині [6]. У

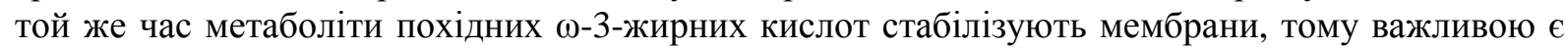
підтримка співвідношення $\omega-3$ до $\omega-6$ ненасичених жирних кислот [18], що реалізується шляхом залучення відповідних елонгаз та десатураз через активацію ядерних рецепторів PPARs, які регулюють перетворення жирних кислот [20]. 3 іншого боку, дані перебудови можуть бути наслідком відповіді на вікасол-індуковану продукцію активних форм оксигену, яка реалізується через активацію кінцевими продуктами розпаду ліпідів транскрипційного фактору Nrf2 [16]. Такий механізм $є$ найбільш вірогідним, оскільки, за результатами попередніх робіт [36], уміст кінцевих продуктів ліпідної пероксидації у досліджених тканинах за тиждень до зареєстрованих змін підвищується. Також у цей період спостерігаються значні достовірні коливання вмісту інших жирних кислот відносно контрольної групи, зокрема підвищуюється на $35,5 \%$ ( $\leq \leq 0.05), 22,8 \%(\mathrm{p} \leq 0.05)$ і $30,9 \%$ ( $\leq \leq 0.05)$ вміст поліненасичених 22:3, 22:6 i $24: 1$.

Наприкінці експерименту в міокарді дослідної групи тварин спостерігається підвищення загальної ненасиченості на 5,7\%, що реалізується за рахунок достовірного підвищення вмісту ненасичених кислот 16:1, 17:1, 18:2, 18:3, 20:1, 22:6 на 98,3\% (p $\leq 0.05), 45,8 \%(\mathrm{p} \leq 0.05), 18,9 \%$ $(\mathrm{p} \leq 0.05), 51,8 \%(\mathrm{p} \leq 0.05), 52,9 \%(\mathrm{p} \leq 0.05), 81,8 \%(\mathrm{p} \leq 0.05)$ порівняно з контролем. У той же час, повністю відсутня в дослідній тканині докозопентаєнова кислота. Особливо варто відзначити підвищення вмісту пальмітоолеїнової кислоти в 1,98 раза $(\mathrm{p} \leq 0.05)$, оскільки ця кислота проявляє цитопротекторний ефект [30] та може використовуватись як субстрат, що підвищує резистентність клітини до пошкоджуючої дії активних форм Оксигену та ліпофільних ксенобіотиків.

Вміст олеїнової кислоти, що формує основний пул жирних кислот, за дії препарату впродовж експерименту, вірогідно, не змінювався, що свідчить про підтримання балансу між прооксидантно-антиоксидантними процесами, оскільки, згідно з літературними даними, вона $\epsilon$ основним ендогенним акцептором активних форм Оксигену (АФО) і лише після окиснення олеїнової кислоти залишкові АФО реагують з іншими НЖК [18].

Також встановлена доволі висока специфічність динаміки вмісту докозопентаєнової кислоти, яка полягає в повному виснаженні ії пулу на 28- і 35- добу за дії препарату. Вміст іншої довголанцюгової полієнової кислоти - 22:6 в міокарді за дії вікасолу достовірно змінювався порівняно 3 контрольною групою впродовж усього експерименту. Однак більш суттєві зміни між групами спостерігались на 35-у добу, що забезпечується шляхом активації ії попереднього синтезу з прекурсору - ліноленової кислоти [23, 32], уміст якої в цей період у міокарді дослідних тварин доволі високий і обумовлений, швидше за все, надходженням цих компонентів із кормами.

Отже, результати роботи можуть бути використані в сільськогосподарській практиці для підвищення якості продукції птахівництва та опірності сільськогосподарської птиці до несприятливих чинників. 


\section{Висновки}

За результатами роботи встановлено специфічну дію вікасолу на вміст окремих жирних кислот у міокарді гусей, зокрема, на 21-шу добу підвищується вміст докозопентаєнової кислоти на $36,3 \%$ при зниженні докозогексаєнової і ліноленової в межах 21-24\%; на 28-му добу підвищується вміст ейкозатетраєнвої і докозогексаєнової кислот при зниженні лінолевої на 22,6\%; на 35-ту добу вміст основних ненасичених жирних кислот (пальмітолеїнової, лінолевої, ліноленової і докозогексаєнової) підвищується при повному виснаженні докозопентаєнової кислоти. Такі зміни призводять до незначного підвищення ненасиченості на 28-му і 35-ту добу, та загального вмісту окремих незамінних жирних кислот на 21-шу, 28-му і 35-ту добу онтогенезу. У цілому, вікасол залежно від фізіологічного стану організму може стимулювати процеси біосинтезу та катаболізму окремих жирних кислот.

1. Aoganghua A., Nishiumi S., Kobayashi K., Nishida M., Kuramochi K., Tsubaki K., Hirai M., Tanaka S., Azuma T., Yoshida H., Mizushina Y., Yoshida M. Inhibitory effects of vitamin $\mathrm{K}_{3}$ derivatives on DNA polymerase and inflammatory activity. International Journal of Molecular Medicine. 2011. Vol. 28 , № 6. P. 937-945. doi: 10.3892/ijmm.2011.773.

2. Arnold W., Giroud S., Valencak T. G., Ruf T. Ecophysiology of Omega Fatty Acids: A Lid for Every Jar. Physiology. 2015. № 30. P. 232-240. doi: 10.1152/physiol.00047.2014.

3. Baran I., Ionescu D., Filippi A., Mocanu M. M., Iftime A., Babes R. Tofolean I. T., Irimia R., Goicea A., Popescu V., Dimancea A., Neagu A., Ganea C. Novel insights into the antiproliferative effects and synergism of quercetin and menadione in human leukemia Jurkat T cells. Leukemia Research. 2014. Vol. 38, № 7. P. 836-849. doi: 10.1016/j.leukres.2014.04.010.

4. Bolton J. L., Dunlap T. Formation and Biological Targets of Quinones: Cytotoxic versus Cytoprotective Effects. Chem Res Toxicol. 2017. Vol. 30, № 1. P. 13-37. doi: 10.1021/acs.chemrestox.6b00256.

5. Carter W. A., Whiteman J. P., Cooper-Mullin C., Newsome S. D., McWilliams S. R. Physiol Biochem Zool. 2019. Vol. 92, № 2. P. 239-251. doi: 10.1086/702667.

6. Cherian G. Nutrition and metabolism in poultry: role of lipids in early diet. Journal of Animal Science and Biotechnology. 2015. Vol. 6, № 1. P. 28. doi: 10.1186/s40104-015-0029-9.

7. Guglielmo C. G. Move that fatty acid: fuel selection and transport in migratory birds and bats. Integr Comp Biol. 2010. № 50. P. 336-45.

8. Hassan G. S. Menadione. Profiles Drug Subst Excip Relat Methodol. 2013. № 38. P. 227-313. doi: 10.1016/B978-0-12-407691-4.00006-X.

9. Huber G. A., Priest S. M., Geisbuhler T. P. Cardioprotective Effect of Hydroxysafflor Yellow A via the Cardiac Permeability Transition Pore. Planta Med. 2018. Vol. 84, № 8. P. 507-518. doi: 10.1055/s-0043122501.

10. Hulbert J. Metabolism and longevity: is there a role for membrane fatty acids? Integr Comp Biol. 2010. № 50. P. 808-817.

11. Jan Y. H., Richardson J. R., Baker A. A., Mishin V., Heck D. E., Laskin D. L., Laskin J. D. Vitamin K3 (menadione) redox cycling inhibits cytochrome P450-mediated metabolism and inhibits parathion intoxication. Toxicology and Applied Pharmacology. 2015. Vol. 288, №1. P. 114-120. doi: 10.1016/j.taap.2015.07.023.

12. Khyzhnyak S. V., Midyk S. V., Sysoliatin S. V., Voitsitsky V. M. Fatty acids composition of inner mitochondrial membrane of rat cardiomyocytes and hepatocytes during hypoxia-hypercapnia. Ukr.Biochem.J. 2016. Vol. 88, № 3. P. 92-98. doi: https://doi.org/10.15407/ubj88.03.092.

13. Kim E. H., Kim M. K., Yun H. Y., Baek K. J., Kwon N. S., Park K. C., Kim D. S. Menadione (Vitamin K3) decreases melanin synthesis through ERK activation in Mel-Ab cells. Eur J Pharmacol. 2013. Vol. 718, № 1-3. P. 299-304. doi: 10.1016/j.ejphar.2013.08.018.

14. Klaiman J. M., Price E. R., Guglielmo C. G. Fatty acid composition of pectoralis muscle membrane, intramuscular fat stores and adipose tissue of migrant and wintering white-throated sparrows (Zonotrichia albicollis). J Exp Biol. 2009. № 212. P. 3865-3872. doi: 10.1242/jeb.034967.

15. Liang S., Ping Z., Ge J. Coenzyme Q10 Regulates Antioxidative Stress and Autophagy in Acute Myocardial Ischemia-Reperfusion Injury. Oxid Med Cell Longev. 2017. № 2017. P. 9863181. doi: $10.1155 / 2017 / 9863181$.

16. Ma Q. Role of nrf2 in oxidative stress and toxicity. Annual Review of Pharmacology and Toxicology. 2013. № 53. P. 401-426. doi: 10.1146/annurev-pharmtox-011112-140320.

17. Marchionatti A. M., Pacciaroni A., Tolosa de Talamoni N. G. Effects of quercetin and menadione on intestinal calcium absorption and the underlying mechanisms. Comparative Biochemistry and Physiology. 
Part A: Molecular \& Integrative Physiology. 2013. Vol. 164, № 1. P. 215-220. doi: 10.1016/j.cbpa.2012.09.007.

18. Marry R., Grenner D., Mayes P., Rodwell V. Biochemistry of Humans [Russian translation], Vol. 2, Mir, Moscow (1993).

19. McCue M. D., O. Amitai, I. Khozin-Goldberg, S. R. McWilliams, and B. Pinshow. Effect of dietary fatty acid composition on fatty acid profiles of polar and neutral lipid tissue fractions in zebra finches, Taeniopygia guttata. Comp Biochem Physiol A Mol Integr Physiol. 2009. № 154. P. 165-172. doi: 10.1016/j.cbpa.2009.06.002.

20. Michalik L, Auwerx J, Berger JP, Chatterjee VK, Glass CK, Gonzalez FJ et al. «International Union of Pharmacology. LXI. Peroxisome proliferator-activated receptors». Pharmacological Reviews. 2006. Vol. 58, № 4. P. 726-741. doi: 10.1124/pr.58.4.5.

21. Molinari C., Morsanuto V., Polli S., Uberti F. Cooperative Effects of Q10, Vitamin D3, and L-Arginine on Cardiac and Endothelial Cells. J Vasc Res. 2018. Vol. 55, № 1. P. 47-60. doi: 10.1159/000484928.

22. Moskalenko N. I., Komarovska-Porohniavets O. Z., Iskiv O. P., Stadnytska N. E. Biological and pharmacological aspects of quinones. Bulletin of Lviv Polytechnic National University. Chemistry, technology of substances and their application. 2008. № 609. P. 124-130.

23. Nakamura M. T., Nara T. Y. Structure, function, and dietary regulation of delta6, delta5, and delta9 desaturases. Annual Review of Nutrition. 2004. № 24. P. 345-376. doi: 10.1146/annurev.nutr.24.121803.063211.

24. Oh S. J., Han H. K., Kang K. W., Lee Y. J., Lee M. Y. Menadione serves as a substrate for P-glycoprotein: implication in chemosensitizing activity. Arch Pharm Res. 2013. Vol. 36, № 4. P. 509-516. doi: 10.1007/s12272-013-0052-3.

25. Palmer F. B. S-C. The extraction of acidic phosphollpids in organic solvent mixtures containing water. Biochim. Biophys Acta. 1971. № 231. P. 134-144. doi: 10.1016/0005-2760(71)90261-x.

26. Salem N. Jr., Litman B., Kim H. Y., Gawrisch K. Mechanisms of action of docosahexaenoic acid in the nervous system. Lipids. 2001. Vol. 36, № 9. P. 945-959. doi: 10.1007/s11745-001-0805-6.

27. Shimozuru M.,. Kamine A., Tsubota T. Changes in expression of hepatic genes involved in energy metabolism during hibernation in captive, adult, female Japanese black bears (Ursus thibetanus japonicus). Comp Biochem Physiol Part B Biochem Mol Biol. 2012. № 163. P. 254-261. doi: 10.1016/j.cbpb.2012.06.007.

28. Skrip M. M., McWilliams S. R. Oxidative balance in birds: An atoms-to-organisms-to ecology primer for ornithologists. J F Ornithol. 2016. № 87. P. 1-20. doi: https://doi.org/10.1111/jofo.12135.

29. Teale M. C. Omega 3 Fatty Acid Research / Teale. - New York: Nova Science Pub Inc., 2006. - 301 c.

30. Titov V. N. Oleic fatty acid, Oleic, linoleic, linolenic low-density lipoproteins. Klin lab diagn. 2006. P. 3-13.

31. Vukomanovic D., Rahman M. N., Bilokin Y., Golub A. G., Brien J. F., Szarek W. A., Jia Z., Nakatsu K. In vitro Activation of heme oxygenase-2 by menadione and its analogs. Med Gas Res. 2014. Vol. 4, № 1. P. 4. doi: 10.1186/2045-9912-4-4.18.

32. Wallis J. G., Watts J. L., Browse J. Polyunsaturated fatty acid synthesis: what will they think of next? Trends in Biochemical Sciences. 2002. Vol. 27, № 9. P. 467. doi: https://doi.org/10.1016/S09680004(02)02168-0.

33. Wiraswati H. L., Hangen E., Sanz A. B., Lam N. V., Reinhardt C., Sauvat A., Mogha A., Ortiz A., Kroemer G., Modjtahedi N. Apoptosis inducing factor (AIF) mediates lethal redox stress induced by menadione. Oncotarget. 2016. Vol. 7, № 47. P. 76496-76507. doi: 10.18632/oncotarget. 12562.

34. Xu J., Tang S., Yin B., Sun J., Song E., Bao E. Co-enzyme Q10 and acetyl salicylic acid enhance Hsp70 expression in primary chicken myocardial cells to protect the cells during heat stress. Mol Cell Biochem. 2017. № 435 (1-2). 73-86. doi: 10.1007/s11010-017-3058-1.

35. Yakoviichuk O. V., Ruban H. V., Danchenko O. O. Influence of vicasol on the activity of Krebs cycle enzymes, antioxidant system and peroxide oxidation in the muscles of geese. Animal Husbandry Products Production and Processing. 2017. Vol. 134, № 1-2. P. 105-112.

36. Yakoviichuk O. V, Danchenko O. O, Danchenko M. M, Fedorko A. S, Haponenko T. M. Influence of vicasol on oxidative reducing processes of myocardium geese. Issues of bioindication and ecology. 2019. 24 (1). C. 133-144. doi: https://doi.org/10.26661/2312-2056/2019-24/1-11.

37. Zdorovtseva L. M, Khromishev V. O, Danchenko O. O. Geese fatty acid composition of brain and heart lipids in hypo-and hyperoxia. Ukrainian Journal of Ecology. 2012; 2 (3): 9-18. doi: dx.doi.org/10.15421/20122_30. 


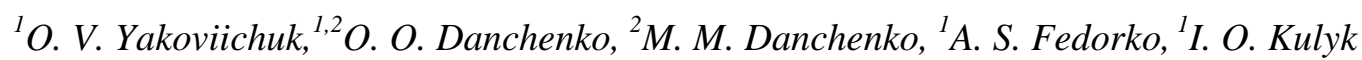

${ }^{1}$ Bohdan Khmelnytsky Melitopol State Pedagogical University, Ukraine

${ }^{2}$ Dmytro Motornyi Tavria State Agrotechnological University, Ukraine

\section{FATTY ACID COMPOSITION OF GOOSE MYOCARDIUM AFFECTED BY VICASOL}

In science vicasol is known to be relative to the energy and antioxidant systems of tissues closely related to the biosynthesis and oxidation of fatty acids. This effect may cause changes in the fatty acid composition of tissues, and numerous works on the positive effect of quinones and their derivatives on the myocardial function, suggest that the proper dose and feeding can increase the stability and productivity of poultry. The given was aims to study the effect of vicasol on the fatty acid composition of goose myocardium.

Myocardium was chosen as a biological object. Biological material was collected every 7 days throughout the period from the 21 st to the 35 th day of ontogeny, characterized by the state of physiological tension of geese. Feeding of geese with vicasol at a dose of $0.7 \mathrm{mg} / \mathrm{kg}$ body weight began with the 3rd day of ontogeny. Fatty acid analysis in myocardial tissues was performed by gasliquid chromatography, pre-fabric samples were processed with the method by Palmer (1971) to obtain tissue lipid extracts.

According to the results of the study, due to various changes in the content of the entire spectrum of fatty acids of the tissue during the experiment - the use of vicasol causes a slight increase in the unsaturation and the total content of unsaturated fatty acids in the myocardium of geese. These fluctuations are realized depending on the physiological state of the body. where vicasol can stimulate both the biosynthesis processes of individual fatty acids and their mitochondrial and microsomal oxidation, as evidenced by multidirectional reliable changes in the content of their entire spectrum. In particular, on the 21st day, the content of docosopentaenoic acid increased by $36.3 \%$ whereas the content of docosohexaenoic and linolenic acids decreased by an average of 21-24\%, on the 28th day the content of eicosatetraic and docosahexaenoic acids increased whereas the content of the linoleic acids dropped by $22.6 \%$ in control groups. On the 35th day, the content of basic unsaturated fatty acids: palmitooleic, linoleic, linolenic and docosohexaenoic acids increased in the tissue under the influence of vicasol with complete depletion of docosopentaenoic acid. These fluctuations in fatty acid composition cause a slight increase in the total content of unsaturated fatty acids and increase the unsaturation of myocardial lipids on the 28th and 35th days of ontogeny of geese. Based on previous results regarding the antioxidant state of myocardium affected by vicasol and the given findings, which prove changes in the content of the entire spectrum of fatty acids during the selected ontogeny, vicasol can be used in poultry farming as a tool to improve the quality and the resilience of poultry.

Key words: vicasol, fatty acids, geese.

Надійшла 26.07.2019. 